\title{
Spatial Variability and Contamination Levels of Fresh Water Resources by Saline Intrusion in the Coastal Low Lying Areas of the Douala Metropolis-Cameroon
}

\author{
Mary Lum Fonteh1,2*, Theophile Fonkou3 ${ }^{3}$ Mathias Fru Fonteh², \\ Estella Buleng Tamungang Njoyim ${ }^{4}$, Cornelius Mbifung Lambi ${ }^{5}$

\begin{abstract}
${ }^{1}$ Department of Geography, Higher Teacher Training College, The University of Bamenda, Bambili, Cameroon
${ }^{2}$ Department of Agricultural Engineering, Faculty of Agronomy and Agricultural Sciences, University of Dschang, Dschang, Cameroon

${ }^{3}$ Department of Plant Biology, Faculty of Science, University of Dschang, Dschang, Cameroon

${ }^{4}$ Department of Chemistry, Higher Teacher Training College, The University of Bamenda, Bambili, Cameroon

${ }^{5}$ Department of Geography, Faculty of Social and Management Sciences, University of Buea, Buea, Cameroon

Email: *mariefontehniba3@gmail.com
\end{abstract}

\begin{abstract}
How to cite this paper: Fonteh, M.L., Fonkou, T., Fonteh, M.F., Njoyim, E.B.T. and Lambi, C.M. (2017) Spatial Variability and Contamination Levels of Fresh Water Resources by Saline Intrusion in the Coastal Low Lying Areas of the Douala MetropolisCameroon. Journal of Water Resource and Protection, 9, 215-237.

https://doi.org/10.4236/jwarp.2017.92015
\end{abstract}

Received: October 12, 2016

Accepted: February 11, 2017

Published: February 14, 2017

Copyright $\odot 2017$ by authors and Scientific Research Publishing Inc. This work is licensed under the Creative Commons Attribution International License (CC BY 4.0).

http://creativecommons.org/licenses/by/4.0/

\begin{abstract}
A study based on the spatial variability and contamination levels of fresh water resources by saline intrusion was conducted in the Douala coastal area. The study was aimed at highlighting the associations between major ions in ground water from which cause-effect relationships could be inferred. Water samples were collected from 19 stations. 3 stations were selected from the mangrove area and 16 stations were selected from the rest of the area partitioned into four transects (coastal transect, inner transect 1, inner transect 2 and inner transect 3). Sampling was done repeatedly during the dry season and these samples were analysed for physico-chemical parameters. Results show that the samples were acidic ( $\mathrm{pH}: 4.7$ - 6.7). Total dissolved solids (TDS) and electrical conductivity (EC) values ranged between $70.3-3703 \mathrm{mg} / \mathrm{L}$ and $136.4-7333 \mu \mathrm{S} / \mathrm{cm}$ respectively indicating medium salt enrichment and brackish waters. High temperatures $\left(\mathrm{T}^{\circ} \mathrm{C}\right)$ and low dissolved oxygen (DO) values of $26^{\circ} \mathrm{C}-30.3^{\circ} \mathrm{C}$ and $0.96-3.9 \mathrm{mg} / \mathrm{L}$ respectively were observed and this could be interpreted as the acceleration of biological and chemical processes of ground water resources. Major ions were within the WHO limits except for $\mathrm{Ca}^{2+}(20.3-85 \mathrm{mg} / \mathrm{L})$ and $\mathrm{Mg}^{2+}(6.6-49.6 \mathrm{mg} / \mathrm{L})$ respectively whose concentrations were slightly higher. The leading cations were $\mathrm{Ca}^{2+}>\mathrm{Na}^{+}>$ $\mathrm{Mg}^{2+}>\mathrm{K}^{+}$while $\mathrm{SO}_{4}^{2-}>\mathrm{Cl}^{-}>\mathrm{NO}_{3}^{-}>\mathrm{HCO}_{3}^{-}>\mathrm{PO}_{4}^{3-}$ were the leading anions. The multivariate analysis approach (MAA) values obtained for water variables showed that F1, F2 and F3 accounted for $61.6 \%, 21.5 \%$ and $9.9 \%$ respectively
\end{abstract}


of total variance with strong loadings and these were considered to account for the ground and surface water quality of the area. The main water types were $63.2 \% \mathrm{Ca}^{2}-\mathrm{SO}_{4}^{2-}, 26.3 \% \mathrm{Ca}^{2+}-\mathrm{Cl}^{-}$and $10.5 \% \mathrm{Na}^{+}-\mathrm{Cl}^{-} .89 .5 \%$ of the water types had secondary salinity implying that anthropogenic sources were the source of salinity. The water was not fit for drinking. The values calculated for percentage sodium and sodium absorption ratio to determine its suitability for agricultural purposes revealed that $63.15 \%, 15.5 \%, 5.3 \%$ and $15.8 \%$ of sampled water were excellent, good, doubtful and unsuitable respectively for irrigation purposes. The need for water resource monitoring and forecasting regarding deterioration in quality is imperative before hazards of the rise in sea level arise.

\section{Keywords}

Spatial Variability, Fresh Water Resources, Salinity Intrusion, Douala IV-Cameroon

\section{Introduction}

The Douala metropolis is the economic hub of the Cameroonian nation with more than $70 \%$ of its industries that have given it a considerable importance in the economy and development of the country. In such an area, utilities including water are quite important for human and industrial growth.

Reference [1] stipulates that water is a basic necessity, underlying the reason why the Millennium Development Goals (MDG) advocated for access to clean water for all by the year 2015. Reference [2] indicated that about $50 \%$ of the Cameroonian population does not have access to safe drinking water. The situation of the Douala coastal area is particularly worrying because water can be found "everywhere although safe portable water is scarce". This area has abundant natural water resources, but the water quality parameters in the area are a dodgy issue. Furthermore, water supplies by the National Water Company fall short of the demand for domestic and industrial use in terms of quantity and quality. Big industries (breweries, textile, chemical, soap factories, agrochemical plants and others) in the area have therefore turned to boreholes for water to meet their needs.

The protection of surface and ground water resources from seawater encroachment is a real issue of concern for coastal communities and this area is similarly affected. The quality of ground water resources in the area could be further complicated by the impact associated with an increasing population, urban development and industrial expansion. In addition, the predictions of increasing rise in the sea level in the area as in [3] [4] and associated hazards in the region may exacerbate the problem in the long term. The salinisation of the water resources could also be due to the formation of large piezometric draw-down cones resulting from the increasing extraction of ground water and this could accelerate salt water intrusion (SWI) by reversing the hydraulic gradients into the aquifers as in [5]. Reference [6] [7] [8] indicated that SWI into coastal aqui- 
fers, rivers and estuaries is one of the impacts that coastal residents will face because of global warming as a result of thermal expansion of oceans and the consequent rise in sea levels. For instance, in North Africa and Iran, communities have been observed to drink water containing as much as $3000 \mathrm{mg} / \mathrm{L}$ of chlorides and $1500 \mathrm{mg} / \mathrm{L}$ of sulphates as in [9]. Reference [10] indicated that, salt water (water containing dissolved salts) is not suitable for drinking because it dehydrates the human body systems and should be desalinated before consumption. As indicated, these ions can act as laxative to those who are not used to drinking such water. Even for industrial and agricultural use, salt water also requires desalinisation and this could imply extra costs.

Understanding the quality patterns of ground water resources is a complex issue because inputs can come from a variety of sources: SWI, ascending deep ground water, precipitation, rapid urbanization and improper waste disposal and high agrochemicals use. It is common knowledge that the spatial variation in chemical composition of ground water comes from different types of input and this is extremely difficult to understand but has important practical applications for water resource management and evaluation as in [5] [7] [11]. Therefore, in order to ensure a rational exploitation of these water bodies, there is a need to understand the interaction of the factors underpinning their quality.

A regular monitoring of the quality of ground water cannot therefore be overemphasized. The on-going study is designed to determine the extent and severity of SWI into water resources of the coastal low lying area of Douala.

\section{Materials and Methods}

\subsection{Study Area}

Douala IV is located within the Douala sedimentary basin with coordinates at latitudes $04^{\circ} 03^{\prime}-04^{\circ} 07^{\prime}$ North of the equator and longitudes $09^{\circ} 37^{\prime}-09^{\circ} 41^{\prime}$ East of the Greenwich meridian with an average elevation of not more than $10 \mathrm{~m}$ above sea level (Figure 1).

The climate is the wet equatorial type and the rainy season extends from April to November, followed by a short dry season typically occurring between December and March. Its annual total rainfall is generally high with values of up to $4000 \mathrm{~mm}$ in August and lower values in the month of February. It has, on the average, 180 rainy days a year. Temperatures are high averaging between $24^{\circ} \mathrm{C}$ and $27^{\circ} \mathrm{C}$. The hydro graphical network within the zone of study is very dense and shows a dendritic pattern. The Wouri River constitutes one of the drainage systems of the Douala metropolis and flows all year round through the Akwa, Bonaberi and part of the Bassa zones. This river is fed by many intermittent streams that are normally loaded with most of the solid and liquid wastes channeled from industries, households and waste dumps.

The area is a sedimentary basin of Cretaceous to Tertiary age having a total surface area of $7000 \mathrm{~km}^{2}$ and has a maximum width of $60 \mathrm{~km}$. Reference [12] noted that the Douala basin consists of the Cretaceous Mungo River Formation, stratigraphically overlain by the Tertiary Mpundu Formation. The Douala 

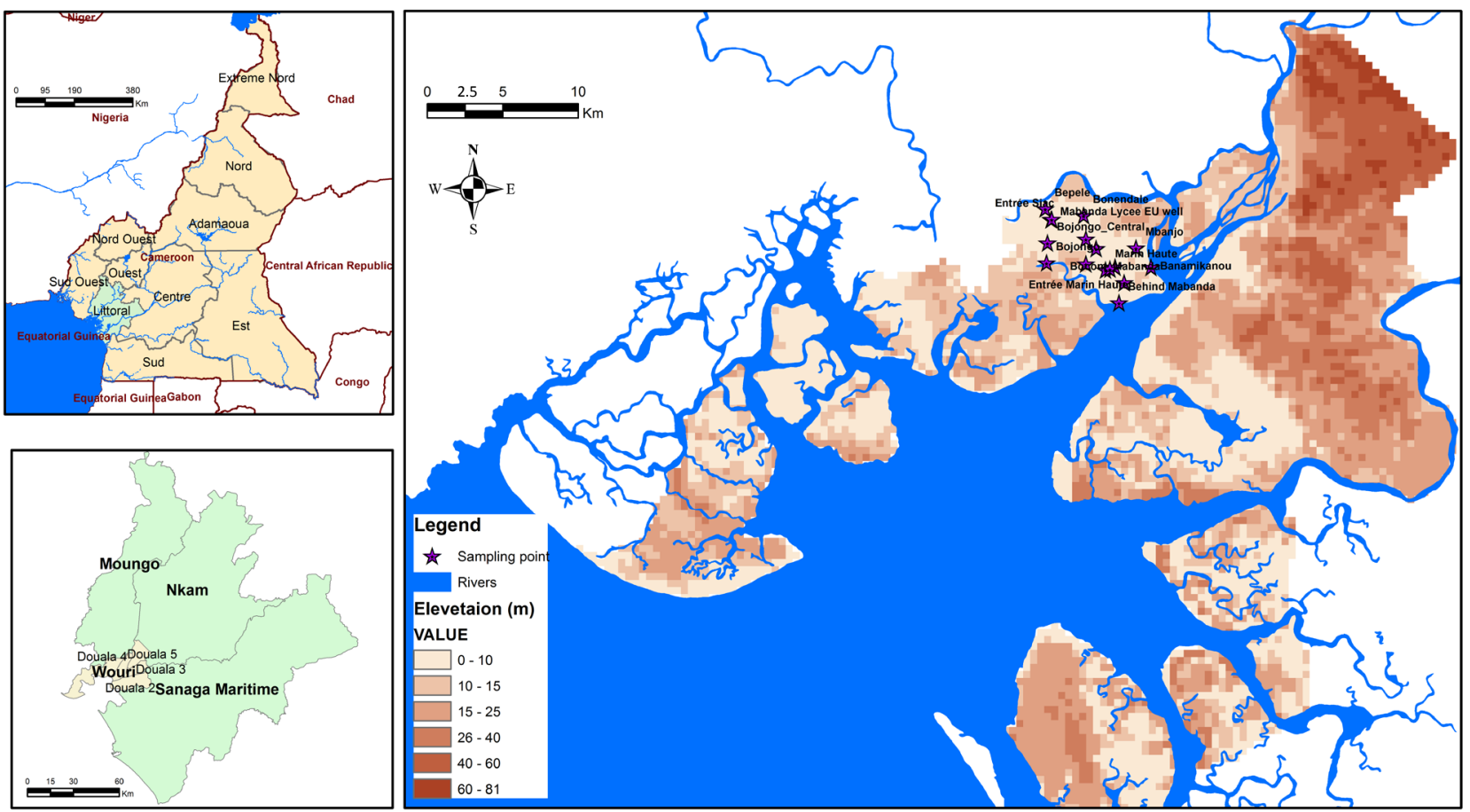

Figure 1. Location of sampling points.

metropolis lies directly on the Mio-Pliocene to Recent alluvial sediments which constitute the Wouri Formation of the Douala basin. It is made up of unconsolidated fine to coarse-grained sand and gravel mixed with silt and clay in various proportions. The alluviums are composed predominantly of quartz and kaolinite with a general thickness that ranges between 50 and $60 \mathrm{~m}$.

Zonal and azonal soils can be distinguished. The sandy ferralitic zonal soils are light coloured, freely drained with top sandy soils and sandy clay sub-soils. These soils are formed in sandy sediments that are rich in quartz with fairly high humus contents. They have a good friability and low water retention capacity; essentially, they result from the decomposition of sedimentary rocks as in [13]. Young azonal (alluvial) soils are found here and have not been sufficiently subjected to the effects of soil forming processes as in [14]. These are immature soils that are good for agriculture.

\subsection{Experimental Design}

Four coastal zone routes in the Douala IV district of Bonassama were selected to check SWI into open wells between November 2014 to May 2015. The locations and altitudes of selected sample sites were determined on the field using a Garmin GPS 60 CX. This enabled the location of the coordinates to produce sample location maps (Figure 1). The routes and 16 of the sampling stations with their location are given in Table 1.

\subsection{Collection and Analysis of Water Samples}

Water was drawn from the open wells using drawing buckets tied with ropes. 
Table 1. Sampling stations and routes.

\begin{tabular}{ccccc}
\hline & $\begin{array}{c}\text { Coastal Transect } \\
\text { (CT) }\end{array}$ & $\begin{array}{c}\text { Inner Station 1 } \\
\text { (IT1) }\end{array}$ & $\begin{array}{c}\text { Inner Station 2 } \\
\text { (IT2) }\end{array}$ & $\begin{array}{c}\text { Inner Station 3 } \\
\text { (IT3) }\end{array}$ \\
\hline Route 1 & Close to EU well & Entre Marin Haute & Bocom (Mabanda) & Bonamikano \\
Route 2 & EU well & Ngwele Entrance & Marche Grand Hangar & Mbanjo \\
Route 3 & Marin Haute & Bojongo & Entree Ndobo & $\begin{array}{c}\text { Ndobo } \\
\text { Slaughter House }\end{array}$ \\
Route 4 & End of Ngwele & Mid way Bojongo & Entrée Siac & Bepele \\
\hline
\end{tabular}

Each water sample was collected into a collector after thorough rinsing with the water to be sampled. Water from the collector was filled into $500 \mathrm{~mL}$ capacity plastic bottles and preserved to avoid evaporation. The samples were stored in ice-chest containers at about $4^{\circ} \mathrm{C}$ prior to laboratory analysis to exclude microbial activity and unwanted chemical activity. Temperature, electrical conductivity (EC), dissolved oxygen (DO), $\mathrm{pH}$ salinity and TDS were measured directly on the field using a DO probe and an $\mathrm{EC} / \mathrm{pH} /$ temperature metre.

Chemical parameters were determined as per standard APHA methods as in [15]. The chemical analyses were performed in the Laboratory for Waste Water Research of the Faculty of Science in the University of Yaounde 1, Cameroon. The total hardness of calcium $\left(\mathrm{Ca}^{2+}\right)$ and magnesium $\left(\mathrm{Mg}^{2+}\right)$ were determined by using the EDTA complexometric titration method; chloride $\left(\mathrm{Cl}^{-}\right)$by the argentometric method; nitrate, sulphate and phosphate measurements were done using ion chromatography on a Dionex ICS-900. Reference [16], indicates that the charge balance calculated should be within the acceptable limit of $\pm 5 \%$. Sodium $\left(\mathrm{Na}^{+}\right)$and potassium $\left(\mathrm{K}^{+}\right)$were analysed by the flame photometric method; salinity was measured using $\mathrm{HACH}$ salinity metre. Bicarbonate $\left(\mathrm{HCO}_{3}^{-}\right)$was measured through titration by adding $0.02-\mathrm{M} \mathrm{HCl}$ solution to the sample while stirring until the endpoint marked by a $\mathrm{pH}$ of 4.5 , was obtained.

To get a clear grasp of the spatial chemical composition of water resources in the Douala IV area, water samples were plotted on a Piper diagram using AQUACHEM software as in [17]. The Wilcox formula was used to determine the $\% \mathrm{Na}$ as in [18]. The physico-chemical properties of ground water resources in Douala IV were further evaluated graphically by plotting EC and sodium absorption ration (SAR) on the United States Salinity (USSL) diagram as in [19].

\section{Results}

\subsection{Physical Characteristics of Water Samples}

A univariate analysis of the physico-chemical data of ground and surface water in Douala IV is presented in Table 2. Water sources characteristics in the study area are not uniform implying that the chemical composition varies over a wide range in physical composition. The average ground water temperature ranged from $27.7^{\circ} \mathrm{C}$ to $30.1^{\circ} \mathrm{C}$ which is slightly higher than the present day, mean atmospheric temperature of $27.62^{\circ} \mathrm{C}$. Ground water usually maintains a fairly constant temperature which, for superficial aquifers, is normally close to the 
Table 2. Statistical summary of physico-chemical data of dry season water resources in the study area.

\begin{tabular}{|c|c|c|c|c|c|c|c|c|c|c|c|c|c|c|c|c|c|c|c|c|}
\hline \multirow{2}{*}{ Parameters } & \multicolumn{4}{|c|}{ Costal transect $(n=4)$} & \multicolumn{12}{|c|}{ Inner transect $1(n=4)$ Inner transect $2(n=4)$ Inner transect $3(n=4)$} & \multicolumn{4}{|c|}{ Surface water $(n=4)$} \\
\hline & Min & $\operatorname{Max}$ & Mean & Std D & Min & $\operatorname{Max}$ & Mean & Std D & Min & $\operatorname{Max}$ & Mean & Std D & Min & $\operatorname{Max}$ & Mean & Std D & Min & $\operatorname{Max}$ & Mean & Std D \\
\hline $\begin{array}{l}\text { Water } \\
\text { Temp. }\end{array}$ & 26 & 29 & 27.7 & 0.81 & 27 & 30.2 & 28.14 & 0.85 & 27 & 28.9 & 27.9 & 0.69 & 26.8 & 29 & 28.02 & 0.69 & 29.9 & 30.3 & 30.1 & 0.21 \\
\hline $\mathrm{pH}$ & 5.16 & 6.52 & 6.07 & 0.39 & 4 & 6.19 & 4.76 & 0.725 & 5.13 & 6.95 & 6.27 & 0.59 & 3.89 & 6.21 & 5.23 & 0.77 & 6.49 & 6.89 & 6.70 & 0.20 \\
\hline Salinity & 0 & 4.2 & 0.825 & 1.28 & 0 & 0.2 & 0.11 & 0.09 & 0 & 1 & 0.3 & 0.4 & 0 & 0.1 & 0.01 & 0.03 & 0.8 & 6 & 4.16 & 2.90 \\
\hline DO & 0.25 & 2.71 & 0.955 & 0.94 & 0.99 & 2.47 & 1.80 & 0.481 & 0.18 & 1.87 & 1.08 & 0.65 & 0.67 & 5.17 & 2.68 & 1.20 & 3.02 & 5.63 & 3.97 & 1.44 \\
\hline TDS & 31 & 3750 & 837.75 & 1112.76 & 25 & 300 & 170.25 & 113.2 & 20 & 965 & 344 & 351 & 32 & 130 & 70.33 & 33.21 & 810 & 5300 & 3703.33 & 2510.2 \\
\hline $\mathrm{NO}_{3}^{-}$ & 0 & 20.14 & 4.495 & 6.86 & 1 & 57.4 & 16.46 & 17.9 & 0.4 & 17.2 & 5.48 & 5.23 & 1.2 & 34 & 10.91 & 9.50 & 0.16 & 3.33 & 1.98 & 1.63 \\
\hline $\mathrm{PO}_{4}^{3-}$ & 0.04 & 5.2 & 1.035 & 1.41 & 0.03 & 6.1 & 0.83 & 1.704 & 0.02 & 1.2 & 0.52 & 0.44 & 0.12 & 1.4 & 0.42 & 0.36 & 0.11 & 0.16 & 0.14 & 0.03 \\
\hline $\mathrm{HCO}_{3}^{-}$ & 0.2 & 5.5 & 1.3125 & 1.49 & 0.1 & 5 & 1.77 & 1.459 & 0.1 & 6.5 & 2.3 & 2.31 & 0.1 & 15 & 2.70 & 4.05 & 0.11 & 1.00 & 0.65 & 0.50 \\
\hline $\mathrm{SO}_{4}^{2-}$ & 8 & 97 & 44.75 & 29.17 & 0 & 43 & 11.17 & 14.58 & 0 & 103 & 47 & 47.5 & 0 & 27 & 10.50 & 11.01 & 59 & 220 & 158 & 86.6 \\
\hline $\mathrm{Ca}^{2+}$ & 20 & 80 & 42.73 & 18.26 & 4 & 84 & 30.67 & 22.26 & 12 & 256 & 85 & 85.4 & 8 & 44 & 20.33 & 10.98 & 12 & 72 & 36 & 31.7 \\
\hline $\mathrm{Mg}^{2+}$ & 2.4 & 69.6 & 21.8 & 21.82 & 0 & 19.2 & 8.20 & 6.428 & 0 & 98.4 & 20.4 & 27.6 & 0 & 31.2 & 6.60 & 9.27 & 12 & 110.4 & 49.6 & 53.1 \\
\hline $\mathrm{Na}^{+}$ & 3 & 73 & 30.92 & 23.11 & 8 & 53 & 20.08 & 11.77 & 3 & 63 & 29.4 & 19.2 & 3 & 123 & 34.58 & 34.05 & 13 & 23 & 16.33 & 5.77 \\
\hline $\mathrm{K}^{+}$ & 0 & 1.47 & 0.45 & 0.58 & 0 & 10.8 & 1.56 & 3.358 & 0 & 9.6 & 1.35 & 3.14 & 0 & 5.47 & 0.64 & 1.55 & 0 & 0.13 & 0.04 & 0.075 \\
\hline $\mathrm{Cl}^{-}$ & 1 & 223.6 & 88.58 & 76.40 & 0 & 95.2 & 19.24 & 27.73 & 0.3 & 61.3 & 17.8 & 18.2 & 0.8 & 34.6 & 7.53 & 9.85 & 9.7 & 243 & 122.9 & 116.81 \\
\hline
\end{tabular}

mean annual air temperature. In this case, the mean of $27.6^{\circ} \mathrm{C}$ was slightly higher than the mean atmospheric temperature of $26.6^{\circ} \mathrm{C}$. This could accelerate the rate of chemical reactions in such systems.

The dissolved oxygen ranged from 0.95 to $2.68 \mathrm{mg} / \mathrm{L}$ for ground water and $3.97 \mathrm{mg} / \mathrm{L}$ for surface water indicating a low degree of solubility. All water samples showed DO of below $5 \mathrm{mg} / \mathrm{L}$. The measurement of DO is critical to the scientific understanding of the potential for chemical and biochemical processes in groundwater. Concentrations below $5 \mathrm{mg} / \mathrm{L}$ may adversely affect the functioning and survival of biological communities and below $2 \mathrm{mg} / \mathrm{L}$ may lead to the death of most fish. The measurement of DO can be used to indicate the degree of pollution by organic matter, the destruction of organic substances and the level of self-purification of the water.

The probable low solubility values could be as a result of higher water temperatures and organic matter pollution. Reference [20] highlighted this fact indicating that low DO could have severe adverse effects on the geochemistry and ecology of different systems.

The entire aquifer system is acidic because all samples (100\%) showed $\mathrm{pH}$ values less than 7. The $\mathrm{pH}$ of ground water ranged from 4.7 to 6.2 (Table 2) indicating that the waters are highly acidic to slightly neutral. Similarly, $\mathrm{pH}$ value of 6.7 for surface waters indicate that they were slightly acidic. The presence of azonal and zonal soils and organic litter from mangroves in the area may have 
contributed to the acidic nature of the well waters. This could probably result from the decomposition of soil organic matter as in [21]. Additionally, poor sewage disposal methods in this area compounded by the intrusion of brackish water into the area could account for the $\mathrm{pH}$ of the water. Reference [22], shows that these processes involve ground water reactions with lateritic soils and humic acids from the decomposition of organic matter in the infiltration zones leading to acidification from dissolved carbon dioxide. Related findings as in [23] attest to this. Reference [24] indicated that acidity in ground water could also result from the reduction in the acid buffering capacity due to soil acidification.

The mean TDS of ground water samples ranged from $70.33-837.75 \mathrm{mg} / \mathrm{L}$ while that for SW stood at $3703.33 \mathrm{mg} / \mathrm{L}$ (Table 2). Most of the ground waters except for two points of the coastal transect, are fresh while the surface water are not fresh following the definitions as in [25] who indicated that TDS values < $1000 \mathrm{mg} / \mathrm{L}$ represent fresh water. The EC readings ranged from $136.4-1661.5$ and 1660 - 10500 for well water and surface water respectively. EC values were distinctly higher at stations close to the coast. The salinity data for this period ranged from 0.008 to 0.825 for IT3 and CT respectively while that for surface water ranged from $0.8-6 \mathrm{mg} / \mathrm{L}$.

Generally, the findings have shown that salinity decreased with an increase in distance from the coastal transects to inner transects as expected. The highest salinity values were for the coastal transects at SW1 and SW2.

The huge variation in TDS of surface water and ground waters of $70.33-837.7$ $\mathrm{mg} / \mathrm{L}$ and $3703.33 \mathrm{mg} / \mathrm{L}$ respectively can be ascribed to the fact that these waters were close to the sea where mangroves could be found, probably indicating an intrusion of salt water. High TDS in water may produce bad taste, odour and colour and may also induce unfavourable physiological reactions in the consumer as in [26]. This could probably account for the bad odour and taste of ground water resources as confirmed by some residents of the study area.

\subsection{Chemical Characteristics of Water Samples}

The leading cation was $\mathrm{Ca}^{2+}$ which had an average percentage concentration of $62.4 \%, 50.6 \%, 44.6 \%$ and $33.3 \%$ as shown in Figure 2 at IT2, IT1, CT, SW and IT3 respectively. This was followed by $\mathrm{Na}^{+}$(55.6\%, 33.19\%, 32.2\%, $21.6 \%$ and $16 \%$ ) in IT3, IT1, CT, IT2 and SW respectively. $\mathrm{Mg}^{2+}$ was the third and $\mathrm{K}^{+}$the last in percentage concentration with values of $48.6 \%$ and $2.1 \%$ in SW and IT1 respectively in that order (Figure 2).

The major anions were sulphate, chloride, nitrate, bicarbonate and phosphate representing 64.29\% (IT2), 63.19\% (CT), 34.03\% (IT3), 8.41\% (IT3) and 1.69\% (IT1) respectively (Figure 3 ). The low $\mathrm{K}^{+}$content was probably due to its low content in rocks of the study area.

Nitrate concentrations indicate that $6.3 \%$ of sample (one sample) exceeded 10 $\mathrm{mg} / \mathrm{L}$ (WHO limit for nitrates in drinking water). The probable sources of nitrates could have been domestic detergents (application of fertilizers and domestic waste waters). 


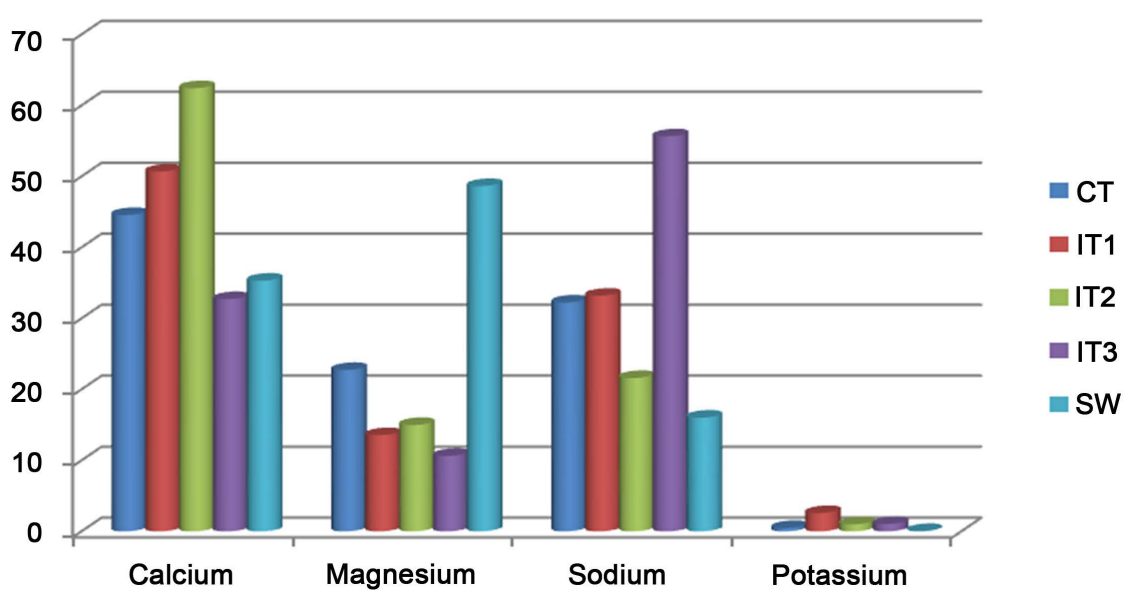

Figure 2. Percentage cations in the different transects.

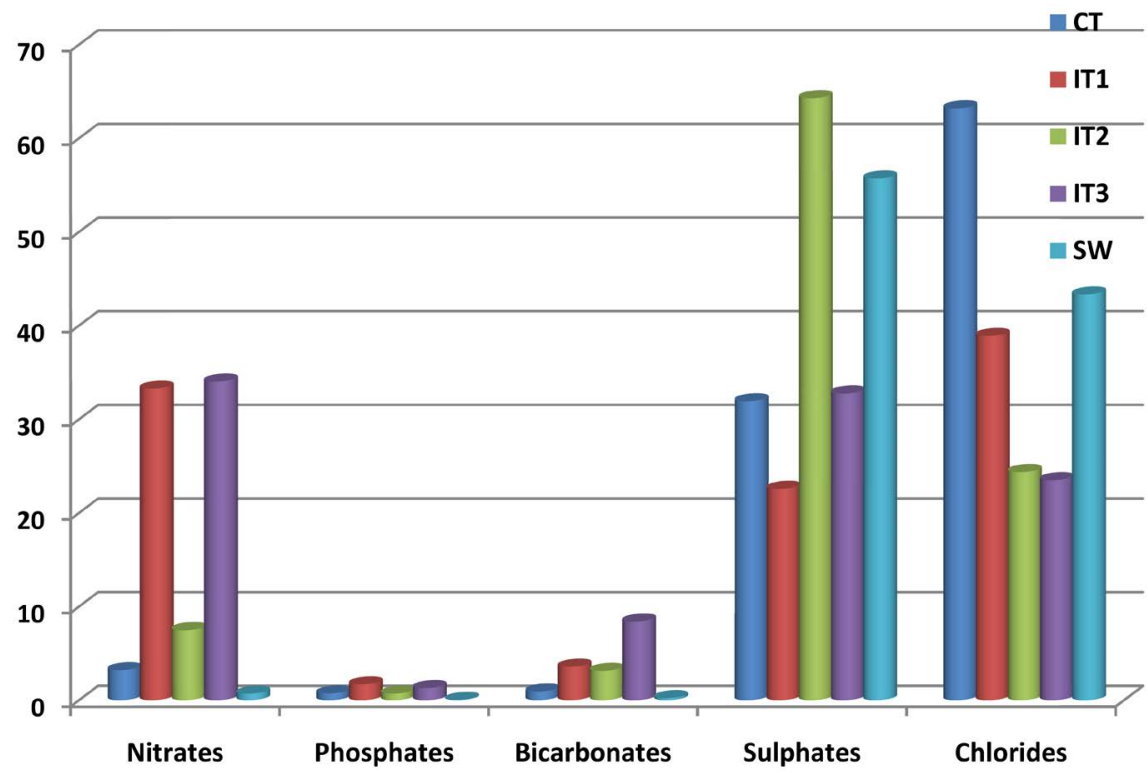

Figure 3. Percentage anions in the different transects.

\subsection{Hydrochemistry of Water Samples}

The Spearman correlation analysis (Table 3 ) indicates the association between key ions in water resources within the area of study. The results highlight a strong regression statistical analysis with $R^{2}$ values of 1 for EC-Salinity, EC-TDS, EC$\mathrm{Mg}^{2+}$, Salinity-TDS, Salinity- $\mathrm{Mg}^{2+}$, TDS- $\mathrm{Mg}^{2+}$. Strong positive correlations of $\mathrm{T}^{\circ} \mathrm{C}-$ $\mathrm{DO}, \mathrm{pH}_{-} \mathrm{SO}_{4}^{2-}, \mathrm{EC}_{-} \mathrm{SO}_{4}^{2-}, \mathrm{EC}-\mathrm{Cl}^{-}$, Salinity- $\mathrm{SO}_{4}^{2-}$, salinity-Cl${ }^{-}, \mathrm{TDS}-\mathrm{SO}_{4}^{2-}$, TDS- $\mathrm{CL}^{-}$of 0.9 suggesting that the different aquifer chemistry is controlled by these parameters as in [27]. A strong positive correlation of 0.9 exists between, $\mathrm{SO}_{4}^{2-}-\mathrm{Mg}^{2+}, \mathrm{Mg}^{2+}-\mathrm{Cl}^{-}$. Another minor correlations of $\mathrm{Na}^{+}-\mathrm{HCO}_{3}^{-}, \mathrm{K}^{+}-\mathrm{HCO}_{3}^{-}$, $\mathrm{Ca}^{2+}-\mathrm{SO}_{4}^{2-}$ of $0.7,0.6$ and 0.7 respectively which further control the aquifer chemistry of the study area was observed.

The correlations between $\mathrm{NO}_{3}^{-}-\mathrm{HCO}_{3}^{-}$and $\mathrm{NO}_{3}^{-}-\mathrm{K}^{+}$of 0.7 and 0.9 respectively could suggest poor sanitation conditions in terms of proximity of toilets to wells and the use of detergents. 
Table 3. Spearman's correlation matrix for water samples in Douala IV.

\begin{tabular}{|c|c|c|c|c|c|c|c|c|c|c|c|c|c|c|c|}
\hline & Water Temp. & $\mathrm{pH}$ & EC & Salinity & DO & TDS & $\mathrm{NO}_{3}^{-}$ & $\mathrm{PO}_{4}^{3-}$ & $\mathrm{HCO}_{3}^{-}$ & $\mathrm{SO}_{4}^{2-}$ & $\mathrm{Ca}^{2+}$ & $\mathrm{Mg}^{2+}$ & $\mathrm{Na}^{+}$ & $\mathrm{K}^{+}$ & $\mathrm{Cl}^{-}$ \\
\hline Water Temp. & 1 & & & & & & & & & & & & & & \\
\hline $\mathrm{pH}$ & 0.1 & 1 & & & & & & & & & & & & & \\
\hline $\mathrm{EC}$ & 0.1 & 0.8 & 1 & & & & & & & & & & & & \\
\hline Salinity & 0.1 & 0.8 & 1 & 1 & & & & & & & & & & & \\
\hline DO & 0.9 & 0.2 & 0 & 0 & 1 & & & & & & & & & & \\
\hline TDS & 0.1 & 0.8 & 1 & 1 & 0 & 1 & & & & & & & & & \\
\hline $\mathrm{NO}_{3}^{-}$ & 0 & -0.9 & -0.9 & -0.9 & -0.1 & -0.9 & 1 & & & & & & & & \\
\hline $\mathrm{PO}_{4}^{3-}$ & -0.7 & -0.5 & -0.1 & -0.1 & -0.9 & -0.1 & 0.3 & 1 & & & & & & & \\
\hline $\mathrm{HCO}_{3}^{-}$ & -0.3 & -0.5 & -0.9 & -0.9 & -0.1 & -0.9 & 0.7 & 0 & 1 & & & & & & \\
\hline $\mathrm{SO}_{4}^{2-}$ & 0.2 & 0.9 & 0.9 & 0.9 & 0.1 & 0.9 & -0.8 & -0.3 & -0.7 & 1 & & & & & \\
\hline $\mathrm{Ca}^{2+}$ & -0.5 & 0.6 & 0.6 & 0.6 & -0.6 & 0.6 & -0.5 & 0.3 & -0.3 & 0.7 & 1 & & & & \\
\hline $\mathrm{Mg}^{2+}$ & 0.1 & 0.8 & 1 & 1 & 0 & 1 & -0.9 & -0.1 & -0.9 & 0.9 & 0.6 & 1 & & & \\
\hline $\mathrm{Na}^{+}$ & -0.7 & -0.4 & -0.6 & -0.6 & -0.4 & -0.6 & 0.3 & 0.3 & 0.7 & -0.7 & -0.2 & -0.6 & 1 & & \\
\hline $\mathrm{K}^{+}$ & -0.1 & -0.7 & -0.7 & -0.7 & -0.3 & -0.7 & 0.9 & 0.4 & 0.6 & -0.5 & -0.1 & -0.7 & 0.1 & 1 & \\
\hline $\mathrm{Cl}^{-}$ & 0.3 & 0.5 & 0.9 & 0.9 & 0.1 & 0.9 & -0.7 & 0 & -1 & 0.7 & 0.3 & 0.9 & -0.7 & -0.6 & 1 \\
\hline
\end{tabular}

The multivariate analysis approach (MAA) has been used in the last years for the assessment of water quality. This is because water quality assessment often requires that several variables be studied concurrently. The use of MAA to link physical and chemical data will enable an overview of the potential cause-effect associated with concentrations of major ions and physical parameters of multi-variable sets as in [28]. MAA values identify the sources and or controlling factors of SWI into the Douala IV coastal ground water as in [29]. It is a multivariate statistical technique to explore variable distributions. The Factor analysis was performed on the correlation matrix that is the variables were auto-scaled (standardized) so as to be treated with equal importance. All analyses were performed using the PCA option of the factor procedure, followed by the basic set-up for factor analysis procedure from the XLSTAT 2015 statistical software.

The present study chose to interpret a variable or group of variables as those associated with a particular factor where loadings were 0.4 or greater, corresponding to an associated explained variance over $65 \%$. This approximates Comrey's (1973) cut-off of 0.55 for a good association between an original variable and a factor and takes into account discontinuities in the magnitudes of loadings approximating these original variables as in [30].

The results of varimax with the Kaiser normalisation rotated factor loading for water resource chemistry data in Douala IV are shown in Table 4 and Figure 4 (biplot) respectively which highlight the controlling factors determining the water chemistry of the study area. These resulting factors are vital because they 
Biplot (axes F1 and F2: $83.12 \%$ )

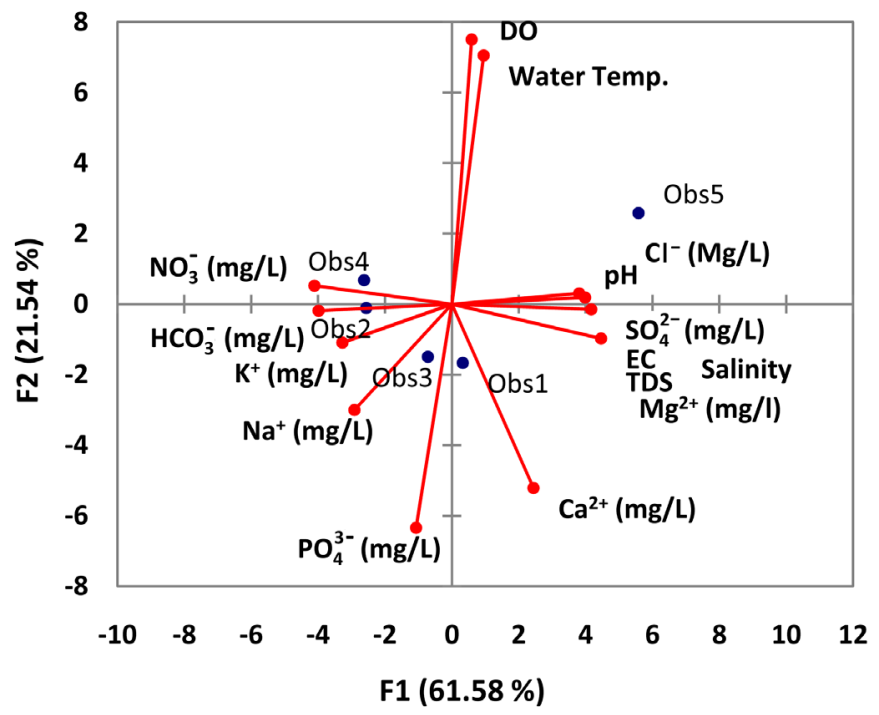

Figure 4. Associations from which cause-effect relationships controlling ground water resources are inferred in the study area.

Table 4. Factor loading, eigenvalues and variances for water resource chemistry data in Douala IV.

\begin{tabular}{|c|c|c|c|c|}
\hline Variables & F1 & F2 & F3 & F4 \\
\hline Water temperature & 0.211 & 0.925 & -0.307 & 0.081 \\
\hline $\mathrm{pH}$ & 0.845 & 0.040 & 0.450 & 0.287 \\
\hline $\mathrm{EC}$ & 0.990 & -0.128 & -0.043 & -0.043 \\
\hline Salinity & 0.990 & -0.128 & -0.043 & -0.043 \\
\hline DO & 0.132 & 0.984 & 0.119 & -0.014 \\
\hline TDS & 0.990 & -0.128 & -0.043 & -0.043 \\
\hline $\mathrm{NO}_{3}^{-} \quad(\mathrm{mg} / \mathrm{L})$ & -0.911 & 0.068 & -0.383 & 0.137 \\
\hline $\mathrm{PO}_{4}^{3-} \quad(\mathrm{mg} / \mathrm{L})$ & -0.238 & -0.832 & -0.448 & -0.226 \\
\hline $\mathrm{HCO}_{3}^{-} \quad(\mathrm{mg} / \mathrm{L})$ & -0.884 & -0.024 & 0.372 & 0.283 \\
\hline $\mathrm{SO}_{4}^{2-} \quad(\mathrm{mg} / \mathrm{L})$ & 0.924 & -0.020 & 0.024 & 0.381 \\
\hline $\mathrm{Ca}^{2+}(\mathrm{mg} / \mathrm{L})$ & 0.542 & -0.684 & 0.068 & 0.484 \\
\hline $\mathrm{Mg}^{2+}(\mathrm{mg} / \mathrm{l})$ & 0.990 & -0.128 & -0.043 & -0.043 \\
\hline $\mathrm{Na}^{+}(\mathrm{mg} / \mathrm{L})$ & -0.646 & -0.393 & 0.567 & -0.325 \\
\hline $\mathrm{K}^{+}(\mathrm{mg} / \mathrm{L})$ & -0.726 & -0.143 & -0.480 & 0.471 \\
\hline $\mathrm{Cl}^{-}(\mathrm{mg} / \mathrm{L})$ & 0.884 & 0.024 & -0.372 & -0.283 \\
\hline Eigenvalue & 9.237 & 3.231 & 1.499 & 1.033 \\
\hline Variability (\%) & 61.582 & 21.540 & 9.992 & 6.886 \\
\hline Cumulative (\%) & 61.582 & 83.122 & 93.114 & 100.00 \\
\hline
\end{tabular}

pinpoint on the controlling processes that lead to the different water facies obtained in this area. Four factor loadings with a $100 \%$ variance explained in the dataset are accounted for from Table 4. The loading of variables on each factor 
and the corresponding percentage of data variance are explained by each factor.

The first principal factor is predorminant and accounts for $61.6 \%$ of the total variance with high positive loadings of $\mathrm{pH}, \mathrm{EC}$, salinity, TDS, $\mathrm{SO}_{4}^{2-}, \mathrm{Ca}^{2+}, \mathrm{Mg}^{2+}$ and $\mathrm{Cl}^{-}$and high negative loadings of $\mathrm{K}^{+}, \mathrm{Na}^{+}, \mathrm{HCO}_{3}^{-}, \mathrm{NO}_{3}^{-}$. This factor can be termed salinity-dissolved solute factor. The first factor determines the main processes that control ground water chemistry. The association of variables (EC, $\mathrm{pH}$, salinity, TDS, $\mathrm{SO}_{4}^{2-}, \mathrm{Ca}^{2+}, \mathrm{Mg}^{+}$and $\left.\mathrm{Cl}^{-}\right)$in factor 1 (61.6\%) of total variance indicates that these variables will impact significantly on the resulting water facies that would be obtained. This is in agreement with the observations as in [24] who indicated that the major ions, $\mathrm{pH}$ and TDS are sensitive to variations in EC. The fact that $\mathrm{SO}_{4}^{2-}, \mathrm{Ca}^{2+}$ and $\mathrm{Cl}^{-}$ions are under factor one, shows their predominance in the determination of the water types.

Reference [31], noted that a high negative loading of variables in a factor shows that they go contrary to the process that generated the negative high loadings. Positive loading indicates the interrelationship of variables that determine the water types of the study area by linking their different concentrations.

The second factor explains $21.5 \%$ variance indicating that the solubility of DO decreases with an increase in temperature; the reason why they could be found under the same factor. MAAs have been carried out as in [32]-[38]. Reference [39] highlighted two factors that were responsible for controlling hydro-chemical processes of ground water in Togo. Their factors were related to the ions with dominant concentrations and therefore the main contributors to groundwater salinity in this study.

Factor 3 was observed to account for $9.9 \%$ of the variance while factor 4 accounted for $6.9 \%$ of the total variance and it is associated with high $\mathrm{pH}$ and $\mathrm{Na}^{+}$ loading and $\mathrm{K}^{+}$, and $\mathrm{Ca}^{2+}$ loadings respectively for factors 3 and 4 . Their preferences in regulating ground water chemistry could therefore be minimal.

The factor analysis does not produce cause effect relationship but highlights the associations from which such cause-effect relationships can be inferred as in [31]. Factor analysis is not used in isolation but it is used with several graphical techniques to make a meaning from hydro-chemical analysis and to identify the water types in the area under investigation. This is why some equations of bivariate plots of EC and chloride and major ions and chloride were exploited together with the Piper diagram to better understand the underlying controlling processes of ground water resources in the study area as in [17].

\subsection{Equations and $R^{2}$ Value from Linear Trend Lines for the Determination of Saline Intrusion}

The association between key ion chemistry is not enough to deduce the causeeffect relationship of hydro-chemical facies. Reference [40] [41] [42] noted that an early indication of SWI into ground water may be a high EC because sea water has a higher EC value than fresh water.

Additionally, an increase in $\mathrm{Cl}^{-}$concentration may be the first indication of SWI into an area devoid of other possible sources of saline contamination. Con- 
sequently, equations and $R^{2}$ value of EC and chloride and major ions and chloride were derived from their corresponding plots to attest to this.

Chloride/EC:

$$
\begin{gathered}
Y=0.0149 x+21.032 \\
R^{2}=0.7782
\end{gathered}
$$

Sodium/chloride:

$$
\begin{gathered}
Y=-0.0765 x+30.183 \\
R^{2}=0.2603
\end{gathered}
$$

Calcium/chloride:

$$
\begin{gathered}
Y=-0.0501 x+45.512 \\
R^{2}=0.0107
\end{gathered}
$$

Magnesium/chloride:

$$
\begin{gathered}
Y=0.2967 x+6.1289 \\
R^{2}=0.7824
\end{gathered}
$$

Sulphate/chloride:

$$
\begin{gathered}
Y=1.0032 x+2.9132 \\
R^{2}=0.7252
\end{gathered}
$$

Equation (1) reveals a good correlation of electrical conductivity and the chloride concentration in Douala IV $\left(R^{2}=0.7782\right)$. This indicates that a mixing between sea water and fresh water are taking place. From Equation (1), the mechanisms of mixing between sea water and fresh water are complex because otherwise, there would have been a perfectly linear correlation between electrical conductivity and the chloride concentration as has similarly been observed as in [43].

From Equation (2), the relationship between sodium and chloride shows a depletion of sodium and a nearly linear relation of calcium and chloride as seen in Equation (3). However, magnesium and sulphate enrichment with chloride, at some points, suggest a strong water aquifer interaction related to direct cation exchange (Equations (4) and (5)). This sample must be from the CT and SW transects as they show a large deviation from the theoretical line of mixing as a result of their high sulphate and magnesium content.

The Piper diagram (Figure 5) indicates the different water types. Reference [44], indicates that the Piper diagram is preferable because it give a better identification of the water samples and the dorminant geo-chemical processes in the water chemistry.

Figure 5, indicates that the water types are of $\mathrm{Ca}^{2+}-2 \mathrm{Cl}^{-}, \mathrm{Na}^{+}-\mathrm{Cl}^{+}, \mathrm{Ca}^{2+}-\mathrm{SO}_{4}^{2-}$ types. Five samples (IT3, 2 IT2 and 2 IT1) representing $26.32 \%$ of the total samples are of the $\mathrm{Ca}^{2+}-\mathrm{Cl}^{-}$type. Two samples (10.53\%) of the total samples are of the $\mathrm{Na}^{+}-\mathrm{Cl}^{-}$type and are found in the IT3 transects and 12 samples (one in IT3, two in IT2, two in IT1, four in CT and three in SW) representing $63.2 \%$ of the total number of samples are of the $\mathrm{Ca}^{2+}-\mathrm{SO}_{4}^{2-}$ facies water type. 


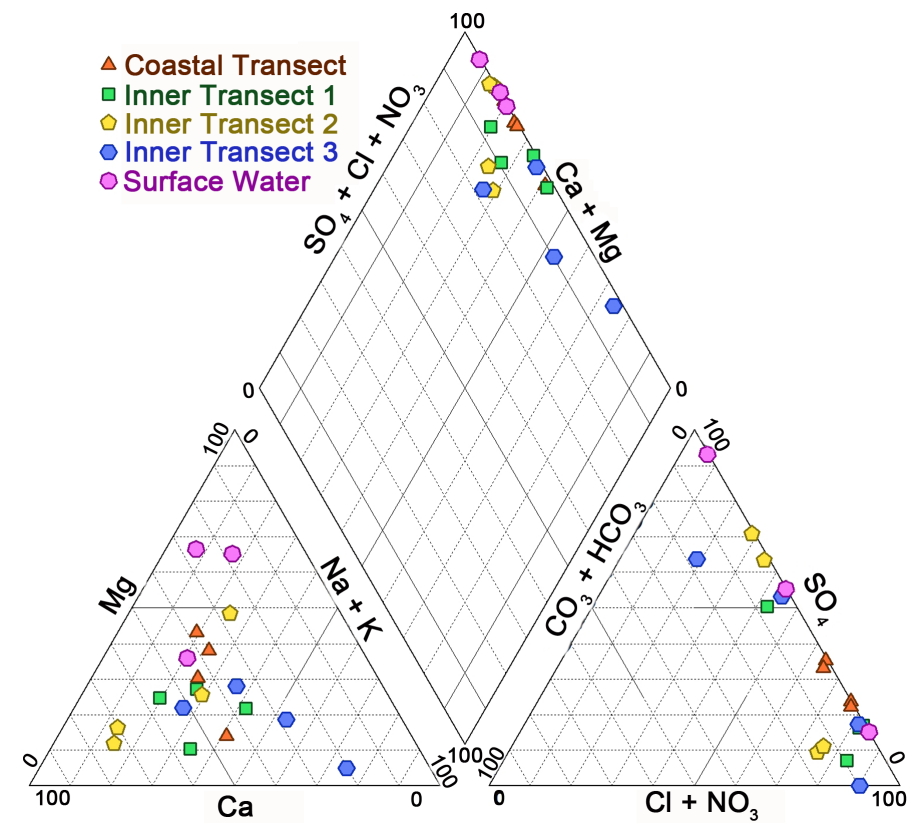

Figure 5. Piper diagram showing the water types and its proportions of Douala IV.

The study shows that the abundance of cations was $\mathrm{Ca}^{2+}>\mathrm{Na}^{+}>\mathrm{Mg}^{2+}>\mathrm{K}^{+}$ indicating that $\mathrm{Ca}^{2+}$ is the most abundant followed by $\mathrm{Na}^{+}, \mathrm{Mg}^{2+}$ and $\mathrm{K}^{+}$. The relative abundance of anions is in the order of $\mathrm{SO}_{4}^{2-}>\mathrm{Cl}^{-}>\mathrm{NO}_{3}^{-}>\mathrm{HCO}_{3}^{-}>\mathrm{PO}_{4}^{3-}$. This indicates that the leading anion is $\mathrm{SO}_{4}^{2-}$ followed by $\mathrm{Cl}^{-}, \mathrm{NO}_{3}^{-}, \mathrm{HCO}_{3}^{-}$ and $\mathrm{PO}_{4}^{3-}$. The likely source of $\mathrm{Ca}^{2+}$ and $\mathrm{SO}_{4}^{2-}$ could be from the dissolution of gypsum and halite as in [45] which could be present in the catchment area. This could be so because a positive correlation matrix of $\mathrm{Ca}^{2+}-\mathrm{SO}_{4}^{2-}\left(R^{2}=0.7\right)$ exists. Reference [46], shows gypsum to be extensively distributed in the subsurface layer of aquifers and generally its dissolution produces calcium and sulphate as seen in Equation (6).

$$
\mathrm{CaSO}_{4} \cdot 2 \mathrm{H}_{2} \mathrm{O} \rightarrow \mathrm{Ca}^{2+}+\mathrm{SO}_{4}^{2}+2 \mathrm{H}_{2} \mathrm{O}
$$

The correlation between $\mathrm{K}^{+}-\mathrm{NO}_{3}^{-} \quad\left(R^{2}=0.9\right)$ suggests a probably poor sanitation conditions in the area.

The majority of samples are depleted in $\mathrm{Na}^{+}$and enriched in $\mathrm{Mg}^{2+}$ and $\mathrm{SO}_{4}^{2-}$ (Equations (2), (4) and (5) respectively). This shows that $\mathrm{Na}^{+}$usually contained in sea water has been replaced by $\mathrm{Ca}^{2+}$ on the one hand, but this could also result from the dissolution of gypsum on the other hand.

\section{Water Resource Suitability with Respect to Saline Water Contamination in Douala IV}

The temperature values were high. This may increase taste, odour, colour and corrosion problems as already apparent in the water sources from field survey. $\mathrm{Ca}^{2+}$ and $\mathrm{Mg}^{2+}$ values were much higher than the WHO norms (Table 5). The presence of these alkaline earth metals signifies water hardness. Though hardness has no adverse effect on human health, there is an aesthetic concern because of the unpleasant taste that it imparts. It can prevent the formation of 
Table 5. Ground water quality in douala IV compared with WHO (2004) safe drinking water standards.

\begin{tabular}{ccc}
\hline Parameters & Range in study area & WHO limits \\
\hline Water temperature $\left({ }^{\circ} \mathrm{C}\right)$ & $26-30.3$ & 15 \\
$\mathrm{pH}$ & $4.7-6.7$ & $6.5-8.5$ \\
$\mathrm{EC}(\mu \mathrm{S} / \mathrm{cm})$ & $136-7388$ & 750 \\
$\mathrm{Salinity}(\mathrm{mg} / \mathrm{L})$ & $0.008-4.167$ & - \\
$\mathrm{DO}(\mathrm{mg} / \mathrm{L})$ & $\mathbf{0 . 9 5 5 - 3 . 9 7 0}$ & $\mathbf{5}$ \\
$\mathrm{TDS}(\mathrm{mg} / \mathrm{L})$ & $70-3703$ & 500 \\
$\mathrm{NO}_{3}^{-}(\mathrm{mg} / \mathrm{L})$ & $1.987-16.458$ & 50 \\
$\mathrm{PO}_{4}^{3-}(\mathrm{mg} / \mathrm{L})$ & $0.143-1.035$ & - \\
$\mathrm{HCO}_{3}^{-}(\mathrm{mg} / \mathrm{L})$ & $0.650-2.696$ & 200 \\
$\mathrm{SO}_{4}^{2-}(\mathrm{mg} / \mathrm{L})$ & $10.50-158$ & 200 \\
$\mathrm{Ca}^{2+}(\mathrm{mg} / \mathrm{L})$ & $20-85$ & 75 \\
$\mathrm{Mg}^{2+}(\mathrm{mg} / \mathrm{L})$ & $\mathbf{6}-49$ & 30 \\
$\mathrm{Na}^{+}(\mathrm{mg} / \mathrm{L})$ & $16-34$ & 200 \\
$\mathrm{~K}^{+}(\mathrm{mg} / \mathrm{L})$ & $0.043-1.559$ & 100 \\
$\mathrm{Cl}^{-}(\mathrm{mg} / \mathrm{L})$ & $7-122$ & 200 \\
\hline & & \\
\hline & & 200 \\
\hline
\end{tabular}

lather with soap, a problem which the inhabitants of CT are already facing. This may also increase the boiling point of water and cause encrustation in the water supply distribution system.

Fresh water resources in Douala IV are vulnerable to acid contamination as the waters from the area are acidic with a range of 4.7 - 6.7 (Table 5). Additionally, the levels of EC are high as in [47]-[52] which is an early indication of SWI. EC is a good measure of salinity hazard on crops because an excess of salinity reduces the osmotic potential of plants and thus interferes with the absorption of water and nutrients from the soil as in [39]. An evaluation of ground water fitness for agricultural uses, based on standards put in place by international organisations as in [53] [54] is imperative.

The analytical plot of the Wilcox formula (Figure 6) shows that sodium is commonly measured for water used for drinking or agricultural purposes. Elevated sodium contents in certain soil types can degrade soil structure thereby restricting water movement and affecting plant growth.

The analysis showed that 12 water samples (representing 63.2\%) were excellent for irrigation; 3 samples (CTc, IT2b, SWa), representing $15.8 \%$ of total number of samples, were good; sample CTb (5.3\%) was doubtful while 3 samples $(\mathrm{CTa}, \mathrm{SWb}, \mathrm{SWc})$, representing $15.8 \%$, were unsuitable for irrigation purposes in term of $\% \mathrm{Na}$ (Table 6).

The sodium adsorption ratio (SAR) was further used to evaluate and confirm the suitability of water for irrigation. The ratio estimates the degree to which sodium will be adsorbed by the soil. High values of SAR, which are related to the 


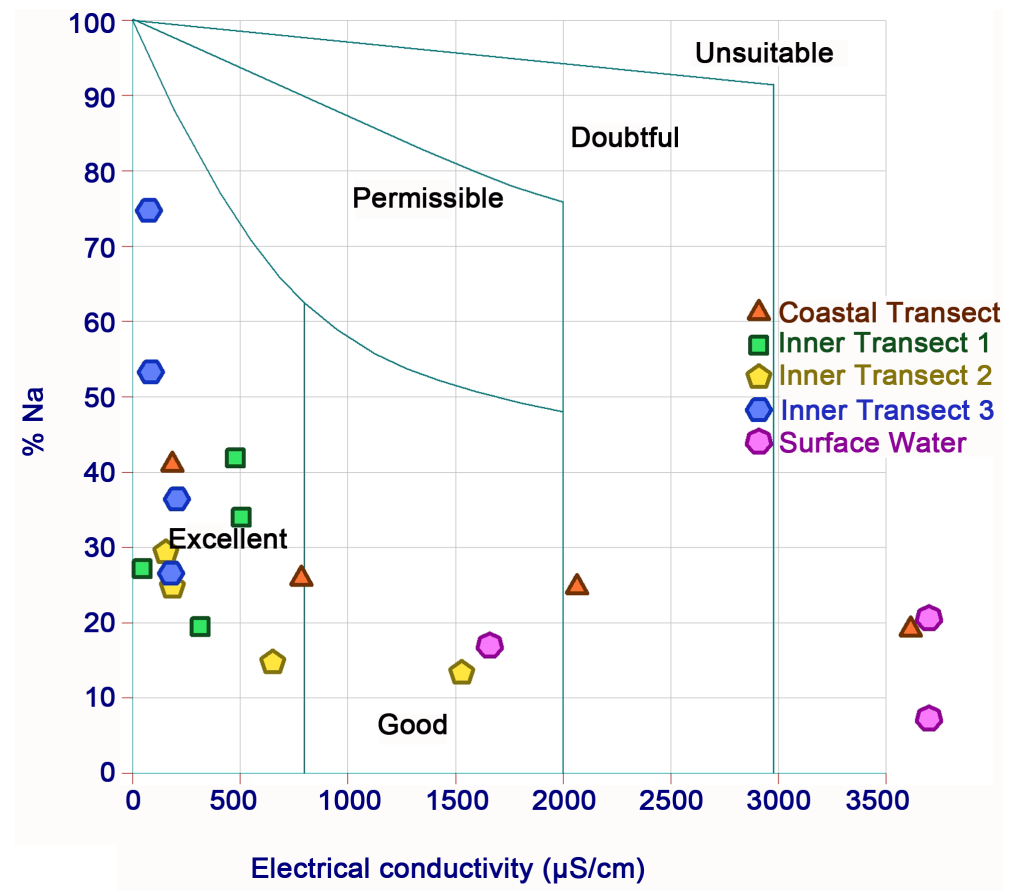

Figure 6. The suitability of water resources in Douala IV for irrigation purposes based on $\% \mathrm{Na}$.

Table 6. Sampled points and corresponding quality of water based on $\% \mathrm{Na}$.

\begin{tabular}{|c|c|c|}
\hline$\% \mathrm{Na}$ & Quality of water & Samples \\
\hline$<20 \%$ & Excellent & $\begin{array}{l}12 \text { (CTd, IT1a, IT1b, IT1c, IT1d, IT2a, } \\
\text { IT2c, IT2d, IT3a, IT3b, IT3c and IT3d) }\end{array}$ \\
\hline $20 \%-40 \%$ & Good & $3(\mathrm{CTc}, \mathrm{IT} 2 \mathrm{~b}, \mathrm{SWa})$ \\
\hline $40 \%-60 \%$ & Permissible & None \\
\hline $60 \%-80 \%$ & Doubtful & $1(\mathrm{CTb})$ \\
\hline $80 \%$ & Unsuitable & $3(\mathrm{CTa}, \mathrm{SWb}, \mathrm{SWc})$ \\
\hline
\end{tabular}

EC, imply that sodium in the irrigation water may replace calcium and magnesium ions in the soil, potentially causing damage to the soil structure as in [39]. Such studies have been carried out elsewhere with promising implications for policy measures as in [55] [56] [57] [58] [59].

The analytical data for ground water chemistry that was plotted on the US salinity diagram (Figure 7) illustrates that 8 samples, representing $42 \%$, are found in the low salinity and low alkalinity (C1S1) area and is good for irrigation purposes.

Four samples (21.1\%) found in the C2S1 type which represents medium salinity and low alkalinity in water qualities showed that the irrigation quality of water was fair in this transects of Douala IV. Type C3S1 had four samples (21.1\%) indicating a high salinity and low alkalinity in water, which can be used for irrigation on almost all types of soils with little danger of exchangeable sodium as in [55]. Three samples however, which represented $15.8 \%$ of total number of samples were found in type C4S1 indicating a very high salinity and low alkalinity and were thus not suitable for agricultural activities as shown on Table 7. 


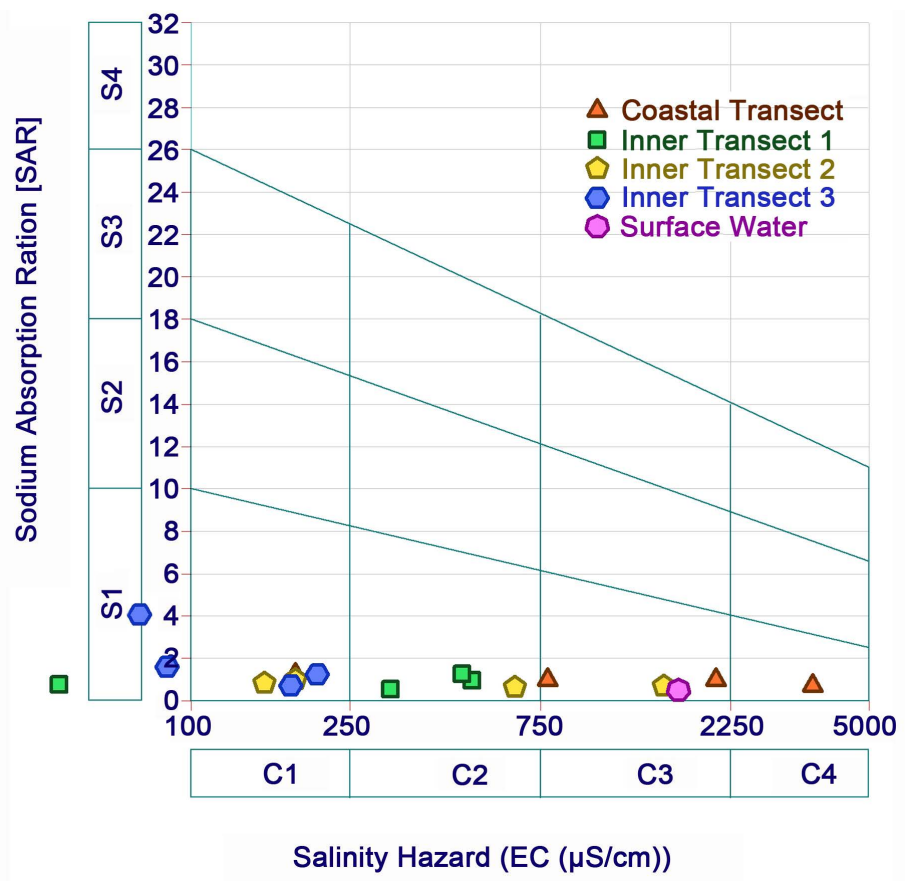

Figure 7. A classification of irrigation waters using the US Salinity diagram.

Table 7. Quality of irrigation water based on electrical conductivity.

\begin{tabular}{ccc}
\hline Salinity hazard class & Specific conductance $(\mu \mathrm{S} / \mathrm{cm})$ & Samples \\
\hline Low & $0-250$ & 8 \\
& $250-750$ & $\left(\begin{array}{c}\text { CTd, IT1d, IT2c, IT2d, IT3a, } \\
\text { IT3b, IT3c and IT3d) }\end{array}\right.$ \\
Medium & $70-2250$ & 4 (IT1a, IT1b, IT1c and IT2a) \\
High & $>2250$ & $4(\mathrm{CTb}, \mathrm{CTc}$, IT2b and SWa) \\
Very high & & $3(\mathrm{CTa}, \mathrm{SWb}, \mathrm{SWc})$ \\
\hline
\end{tabular}

The spatial variation (CT, IT1, IT2, IT3 and SW) and contamination of ground and surface water resources in the low lying area of the Douala IV metropolis were assesed using both physical and chemical parameters (EC, $\mathrm{pH}$, salinity, TDS, concentrations of $\left.\mathrm{Na}^{+}, \mathrm{SO}_{4}^{2-}, \mathrm{Mg}^{2+}, \mathrm{Ca}^{2+}, \mathrm{Cl}^{-}\right)$. Two points of ground water of IT3 were located close to the Wouri River and the other two were far inland from the coast. These waters are rich in $\mathrm{Na}^{+}, \mathrm{Ca}^{2+}, \mathrm{Cl}^{-}$and exhibit all the water types $\left(\mathrm{Ca}^{2+}-\mathrm{Cl}^{-}, \mathrm{Ca}^{2+}-\mathrm{SO}_{4}^{2-}\right.$ and $\left.\mathrm{Na}^{+}-\mathrm{Cl}^{-}\right) . \mathrm{Na}^{+}-\mathrm{Cl}^{-}$water types indicates that the water type undergoes primary salinity while $\mathrm{Ca}^{2+}-2 \mathrm{Cl}^{-}$ and $\mathrm{Ca}^{2+}-\mathrm{SO}_{4}^{2-}$ water types suggest a possible mixing with sea water.

Two points each from the IT2 and IT1 are of the $\mathrm{Ca}^{2+}-\mathrm{SO}_{4}^{2-}$ water types and the other two points are of the $\mathrm{Ca}^{2+}-2 \mathrm{Cl}^{-}$water type. All sample points from CT and $\mathrm{SW}$ are of the $\mathrm{Ca}^{2+}-\mathrm{SO}_{4}^{2-}$ water types. These suggest that secondary salinity is taking place at these points indicating pollution from domestic and leaking sewage and that the processes controlling ground water chemistry in the area are varied. 


\section{Discussion}

The interpretation of hydro-chemical analysis in the present study showed that $\mathrm{NO}_{3}^{-}, \mathrm{PO}_{4}^{3-}, \mathrm{HCO}_{3}^{-}, \mathrm{SO}_{4}^{2-}, \mathrm{Na}^{+}, \mathrm{K}^{+}$, and $\mathrm{Cl}^{-}$met the guideline limits while $\mathrm{T}^{\circ} \mathrm{C}, \mathrm{pH}, \mathrm{EC}, \mathrm{DO}, \mathrm{TDS}, \mathrm{Ca}^{2+}$ and $\mathrm{Mg}^{2+}$ were above WHO limits.

MAA values obtained for water variables showed that F1, F2 and F3 accounted for $61.6 \%, 21.5 \%$ and $9.9 \%$ respectively of total variance with strong loadings and these were considered to determine the ground and surface water qualities of the area. F4 was not considered due to a much lower variance (6.8\%). The study indicated calcium followed by sodium to be the most abundant cations. Sulphate was the most abundant anions. Furthermore, most samples were depleted in sodium and enriched in magnesium and sulphate from Equations (2), (4) and (5) respectively.

Reference [5] [31] [47] [48] [49] [50] indicated that depletion in $\mathrm{Na}^{+}$and a gain in $\mathrm{Mg}^{2+}$ and $\mathrm{Ca}^{2+}$ highlight a direct cation exchange observed in situations where sea water is replacing fresh water. When SWI occurs, there is the favoured release of $\mathrm{Mg}^{2+}$ and $\mathrm{Ca}^{2+}$ from exposed bedrock due to weathering of clay minerals. Consequently, free $\mathrm{Cl}^{-}$anions are released and there is the adsorption of $\mathrm{Na}^{+}$ onto mineral surfaces. The fact that $\mathrm{Ca}^{2+}$ and $\mathrm{Mg}^{2+}$ ions are released and $\mathrm{Na}^{+}$are engrossed points to salinization of water resources in the study area. $\mathrm{Ca}^{2+}$ is however one of the major cations and this suggests the existence of other sources contributing to the enrichment of groundwater. This could be substantiated by the dissolution of gypsum and associated minerals in the aquifer.

Piper diagrams illustrated that water types are of $\mathrm{Ca}^{2+}-\mathrm{SO}_{4}^{2-}(63.2 \%), \mathrm{Na}^{+}-$ $\mathrm{Cl}^{-}(10.53 \%)$ and $\mathrm{Ca}^{2+}-2 \mathrm{Cl}(26.32 \%)$ type. This shows that all water types are made up of strong acid ions $\left(\mathrm{SO}_{4}^{2-}, \mathrm{Cl}^{-}\right)$which exceed weak acids $\left(\mathrm{HCO}_{3}^{-}\right.$and $\left.\mathrm{CO}_{3}^{2-}\right)$. Alkaline earths $\left(\mathrm{Ca}^{2+}\right.$ and $\left.\mathrm{Mg}^{2+}\right)$ exceed alkalis $\left(\mathrm{Na}^{+}\right.$and $\left.\mathrm{K}^{+}\right)$in all samples $(89.5 \%)$ except for two from IT3. Figure 5 illustrates that these samples are of non-carbonate hardness, indicating that secondary salinity exceeds $50 \%$ and the main properties are dominated by alkaline earths and strong acid ions. This explains why the water types are of $\mathrm{Ca}^{2+}-\mathrm{SO}_{4}^{2-}$ and $\mathrm{Ca}^{2+}-2 \mathrm{Cl}^{-}$type and implies that the water types are from formations that could be composed of dolomite and limestone or from active recharge zones with short residence times as in [36]. Two samples from IT3 are of alkaline carbonate (primary salinity exceeds $50 \%$ ) and its chemical properties are dominated by alkalis and weak acids, hence this water type is of the $\mathrm{Na}^{+}-\mathrm{Cl}^{-}$type. These water types could be originating from halite dissolution (saline) or alkaline carbonate enrichment.

Primary salinity implies that the acquisition of salts is a result of natural dissolution of the underlying rocks in the study area and this is seen in two samples from IT3 representing $10.53 \%$ of total water types. The other two points which are far from the coastal transects must have started witnessing secondary salinity. The SW, CT, IT1 and IT2 are all experiencing secondary salinity, implying that either salt water from the ocean is gradually intruding into fresh water aquifers or the high rate of urbanisation is influencing secondary salinity. This could pose a fundamental problem to ground water resources in the future if nothing is 
done.

The rest, $89.5 \%$ of water types is a result of anthropogenic activities, termed secondary salinization. $26.3 \%$ of this water type is of the $\mathrm{Ca}^{2}{ }^{+}-2 \mathrm{Cl}^{-}$type. Reference [21] indicated that the occurrence of $\mathrm{Ca}^{2+}-2 \mathrm{Cl}^{-}$water type in coastal aquifers signifies an active process of sea water mixing where $\mathrm{Na}^{+}$from sea water is exchanged for $\mathrm{Ca}^{2+}$ adsorbed on clays. $\mathrm{Ca}^{2+}-2 \mathrm{Cl}^{-}$water types have developed in this area and the $\mathrm{Na}^{+}-\mathrm{Cl}^{-}$water type occur close to the River Wouri. However, Reference [51] indicated that $\mathrm{Ca}^{2+}-2 \mathrm{Cl}^{-}$water types do not develop in the study area. Contrarily, this study underlines the fact that the area was experiencing salinisation. These differences could be attributed to the spatial differences in the studies. Additionally, Reference [36] indicate that typical sea water mixing or base ion exchange is observed in study areas when some water samples belonged to the $\mathrm{Na}-\mathrm{Cl}$ and $\mathrm{Na}-\mathrm{HCO}_{3}{ }^{-}$water types. Two samples representing $10.53 \%$ of total samples analysed are of the $\mathrm{Na}^{+}-\mathrm{Cl}^{-}$water type, implying that sea water mixing or base ion exchange occurs in the study area.

Other probable sources of secondary salinity in this area could be urbanization and industralisation activities. However, inhabitants of Douala IV do not carry out agricultural activities intensively and consequently; the most probable sources of secondary salinity could be urbanization and sea water intrusion into coastal aquifers.

Several authors have noted saline water intrusion into coastal aquifers as a major concern with hazards of probable rise in sea level aggravating the situation as in [60] [61] [62]. This constitutes the most common of all the pollutants of freshwater. Therefore, an understanding of saline intrusion is essential for the management of coastal water resources as in [56].

Varied studies on water quality for different end uses have been carried out in Cameroon. Reference [34], in their study centered on the suitability of ground water for drinking, domestic and agricultural uses in the banana plantation plains of Njombe, concluded that nitrate contamination is taking place. Reference [51] concluded that ground water in a highly urbanised coastal area is vulnerable to acid deposition. Reference [63], in their study, indicated that the continuous use of River Wouri and Dibamba for domestic puposes is unsafe and needs attention. Reference [22] in their different studies for the Gulf of Guinea and of Ndop plain respectively indicated that more than $50 \%$ of the water sources studied were suitable only for drinking and irrigation purposes. Their studies did not focus on water quality fitness with regards to hazards of a rise in sea level. Such studies as in Douala IV which is the economic capital of the nation, are thus vital in Cameroon. This study has higlighted a very comtempory issue that needs to be addressed before it gets out of hand. Raising awareness as in [64] to the inhabitants of this area to the effects of of SLR hazards is important. Additionally the use of spatial data sets as in [65] as an initial requirement in depicting most vulnerable areas should be envisaged.

\section{Conclusions}

The interpretation of hydro-chemical analysis in the present study showed that 
$\mathrm{NO}_{3}^{-}, \mathrm{PO}_{4}^{3-}, \mathrm{HCO}_{3}^{-}, \mathrm{SO}_{4}^{2-}, \mathrm{Na}^{+}, \mathrm{K}^{+}$, and $\mathrm{Cl}^{-}$met the guideline limits while $\mathrm{T}^{\circ} \mathrm{C}, \mathrm{pH}, \mathrm{EC}, \mathrm{DO}, \mathrm{TDS}, \mathrm{Ca}^{2+}$ and $\mathrm{Mg}^{2+}$ were above WHO limits. MAA values obtained for water variables showed that F1, F2 and F3 accounted for 61.6\%, $21.5 \%$ and $9.9 \%$ respectively of total the variance with strong loadings and these were considered to determine the ground and surface water qualities of the area. F4 was not considered due to a much lower variance (6.9\%). The piper diagrams illustrated that water types are of $\mathrm{Ca}^{2+}-\mathrm{SO}_{4}^{2-}(63.2 \%), \mathrm{Na}^{+}-\mathrm{Cl}^{-}(10.5 \%)$ and $\mathrm{Ca}^{2+}-2 \mathrm{Cl}(26.3 \%)$ type. All samples except two from IT3 (89.5\%) were dominated by more than $50 \%$ of alkaline earth ions $\left(\mathrm{Ca}^{2+}\right.$ and $\left.\mathrm{Mg}^{2+}\right)$ and strong acid anions. These samples exhibited non-carbonate hardness indicating that the secondary salinity of ground water dominates over primary salinity. $10.5 \%\left(\mathrm{Na}^{+}-\mathrm{Cl}^{-}\right)$of total number of samples indicated seawater with a $\mathrm{Na}^{+}$dorminant type or $\mathrm{Cl}^{-}$ dorminant type waters indicating typical salinity through seawater mixing .

The main processes that determine the water types of the study area were: 1 ) reversed ion exchange which is a situation that occurs when alkaline earths metal ions $\left(\mathrm{Ca}^{2+}+\mathrm{Mg}^{2+}\right)$ are in excess of alkali ions $\left(\mathrm{Na}^{+}+\mathrm{K}^{+}\right)$and strong acid ions exceed weak acid ions and; 2) basic ion exchange processes which entails residual sodium carbonate disposition in the area, a situation in which $\mathrm{Na}^{+}-\mathrm{Cl}^{-}$water types were identified in the study.

$10.5 \%$ of water facies of IT3 were of primary salinity while $89.5 \%$ of water types were of secondary salinity. This could be attributable to gradual salt water intrusion from the sea into the aquifers as observed in the order of SW >CT > IT1 > IT2 > IT3. However, it could also have resulted from urbanization, although it was not clear which urban activities could have provoked the salinization of ground water resources. The fact that two sample points of IT3 experienced secondary salinity did not mean that they constitute a major health hazard in the future.

According to the Wilcox formula and the USSL diagram (Figure 7), 15.8\% of the ground water samples were not suitable for irrigation purposes. The demand for water has increased resulting in an associated acute shortage of water to meet the daily water consumption needs of the people. Most of the residents of Douala depend on borehole wells for domestic, industrial and agricultural use. Present and future palatability of ground water resources for domestic purposes in Douala IV will go a long way to ensure public health and serve for important practical application of water resource management in the area.

\section{References}

[1] AWDR (African Water Development Report) (2006) Freshwater Resources in Africa. $380 \mathrm{p}$. http://www.fanrpan.org/documents/d00367/African_Water_Development_Report_ 2006.pdf

[2] Gleick, P.H. (1998) The World's Water: The Biennial Report on Freshwater Resources. Island Press, Washington DC, 7-14.

[3] Fonteh, M., Esteves, L.S. and Gehrels, W.R. (2009) Mapping and Valuations of Ecosystems and Economic Activities along the Coasts of Cameroon: Implications of 
Future Sea Level Rise. Coastline Reports, 13, 47-63.

[4] Ndenecho, E.N. and Fonteh, M.L. (2012) Freshwater and Coastal Resource Management in Cameroon: Building Resistance and Resilience to Climate Change. Agwecams Printers, Bamenda, 328 p.

[5] Zghibi, A., Tarhouni, J. and Zouhri, L. (2013) Assessment of Seawater Intrusion and Nitrate Contamination on the Groundwater Quality in the Korba Coastal Plain of Cap-Bon (North-East of Tunisia). Journal of African Earth Sciences, 87, 1-12. https://doi.org/10.1016/j.jafrearsci.2013.07.009

[6] Yang, G. (1992) Impacts of Future Sea Level Rise on Salt Water Intrusion in the Changjiang River Estuary. Chinese Geographical Science, 2, 30-41. https://doi.org/10.1016/j.jafrearsci.2010.01.004

[7] Emmanuel, B.E. and Chukwu, L.O. (2010) Spatial Distribution of Saline Water and Possible Sources of Intrusion into a Tropical Freshwater Lagoon and the Transitional Effects on the Lacustrine Ichthyofaunal Diversity. African Journal of Environmental Science and Technology, 4, 480-491.

[8] Murgulet, D. and Tick, G.R. (2008) Assessing the Extent of Saltwater Intrusion in the Aquifer System of Southern Baldwin County. Alabama Naples 4 p.

[9] Cairncross, S. and Feachem, R.G. (1983) Environmental Health Engineering in the Tropics: An Introductory Text. John Wiley \& Sons, Hoboken, 283 p.

[10] Conner, S.L. and Freeman, L.A. (1998) Drinking Water Quality. Waterworks Publishing, Florida, $31 \mathrm{p}$.

[11] Desai, B. and Desai, H. (2012) Assessment of Water Quality Index for Ground Water with Respect to Salt Water Intrusion at Coastal Region of Surat City, Gujarat, India. Journal of Environmental Research and Development, 7, 607-621.

[12] Ntamak-Nida, M.J., Bourquin, S., Makong, J., Baudin, F., Mpesse, J.E., Ngouem, C.I., et al. (2010) Sedimentology and Sequence Stratigraphy from Outcrops of the Kribi-Campo Sub-Basin: Lower Mundeck Formation (Lower Cretaceous, Southern Cameroon). Journal of African Earth Sciences, 58, 1-18.

https://doi.org/10.1016/j.jafrearsci.2010.01.004

[13] Gavaud, M. and Muller, J.P. (1980) Soils Atlas of the United Republic of Cameroon. Jeune Afrique, Paris, $51 \mathrm{p}$.

[14] Neba, A.S. (1999) Modern Geography of the Republic of Cameroon. 2nd Edition, Neba Publishers, Camden, 200 p.

[15] APHA/AWWA/WEP (2005) Standard Methods for the Examination of Water and Wastewater. 21st Edition, APHA, AWWA, and WEF, $1368 \mathrm{p}$.

[16] Domenico, P.A. and Schwartz, F.W. (1990) Physical and Chemical Hydrogeology. John Wiley and Sons, Hoboken, Vol. 411, 485-497.

[17] Piper, A.M. (1944) A Graphic Procedure in the Geochemical Interpretation of Water Analyses. American Geophysical Union Transactions, 25, 914-923. https://doi.org/10.1029/TR025i006p00914

[18] Wilcox, L.V. (1955) Classification and Use of Irrigation Waters. US Department of Agriculture Circular 969, Washington DC, 367 p.

[19] Richard, L.A. (1954) Diagnosis and Improvement of Saline and Alkalis Soils. Agric. Handbook 60, US Dept. Agric., Washington DC, 160 p.

[20] Best, M.A., Wither, A.W. and Coates, S. (2007) Dissolved Oxygen as a Physico-Chemical Supporting Element in the Water Framework Directive. Marine Pollution Bulletin, 55, 53-64. https://doi.org/10.1016/j.marpolbul.2006.08.037

[21] Appelo, C.A.J. and Postma, D. (1996) Geochemistry, Groundwater and Pollution. 
AA Balkema, Rotterdam, $536 \mathrm{p}$.

[22] Wotany, E.R., Ayonghe, S.N., Fantong, W.Y., Wirmvem, M.J. and Ohba, T. (2013) Hydrogeochemical and Anthropogenic Influence on the Quality of Water Sources in the Rio del Rey Basin, South Western, Cameroon, Gulf of Guinea. African Journal of Environmental Science and Technology, 7, 1053-1069.

[23] Ako, A.A. (2011) Hydrological Study on Ground Water in the Banana Plain and Mount Cameroon Area-Cameroon Volcanic Line (CVL). PhD Dissertation. Kumamoto University, Kumamoto, 222 p.

[24] Chapman, D. (1996) Water Quality Assessments: A Guide to the Use of Biota, Sediments and Water in Environmental Monitoring. UNESCO/WHO/UNEP, Taylor \& Francis Ltd., Milton Park, 609 p. https://doi.org/10.4324/NOE0419216001

[25] Freeze, R.A. and Cherry, J.A. (1979) Groundwater. 2nd Edition, Prentice Hall, Eaglewood Cliff, $604 \mathrm{p}$.

[26] Spellman, F.R. and Drinan, J. (2000) The Drinking Water Handbook. Technomic Publishing Company Inc., Lancaster, 260 p.

[27] Odoh, B.I., Utom, A.U., Egboka, B.C.E. and Okeke, H.C. (2012) Geoelectric Sounding for Predicting Shallow Aquifer Properties Using Modified Archie Equations. Paper Presented at the SEG-AGU Hydrogeophysics Workshop, Boise State University, Boise.

[28] Gauch Jr., H.G. (1982) Multivariate Analysis in Community Ecology. Cambridge University Press, Cambridge, 298 p. https://doi.org/10.1017/CBO9780511623332

[29] Riba, I., Zitko, V., Forja, J.M. and DelValls, T.A. (2003) Deriving Sediment Quality Guidelines in the Guadalquivir Estuary Associated with the Aznalcolar Mining Spill. A Comparison of Different Approaches. Ciencias Marinas, 29, 261-264.

[30] Comrey, A.L. (1973) A First Course in Factor Analysis. Academic Press, New York, $342 \mathrm{p}$.

[31] Yidana, S.M., Banoeng-Yakubo, B. and Sakyi, P.A. (2012) Identifying Key Processes in the Hydrochemistry of a Basin through the Combined Use of Factor and Regression Models. Journal of Earth System Science, 121, 491-507. https://doi.org/10.1007/s12040-012-0163-0

[32] Seyf-Laye, A.M., Mingzhu, L., Fei, L., Djaneye-Bouindjou, G., Moctar, L.B. and Honghan, C. (2011) Factor Analysis as an Example of Qualitative and Quantitative Method for Modeling Hydrogeochemical Processes of Coastal Sedimentary Basin of Togo. African Journal of Microbiology Research, 5, 5554-5559.

[33] Gnazou, M.D.T., Bawa, L.M., Banton, O. and Djanéyé-Boundjou, G. (2011) Hydrogeochemical Characterization of the Coastal Paleocene Aquifer of Togo (West Africa). International Journal of Water Resources and Environmental Engineering, 3, 10-29.

[34] Ako, A.A., Shimada, J., Hosono, T., Ichiyanagi, K., Nkeng, G.E., Fantong, W.Y., et al. (2011) Evaluation of Groundwater Quality and Its Suitability for Dinking, Domestic, and Agricultural Uses in the Banana Plain (Mbanga, Njombe, Penja) of the Cameroon Volcanic Line. Environmental Geochemistry and Health, 33, 559-575. https://doi.org/10.1007/s10653-010-9371-1

[35] Yidana, S.M. (2010) Groundwater Classification Using Multivariate Statistical Methods: Southern Ghana. Journal of African Earth Sciences, 57, 455-469. https://doi.org/10.1016/j.jafrearsci.2009.12.002

[36] Ravikumar, P. and Somashekar, R.K. (2015) Principal Component Analysis and Hydrochemical Facies Characterization to Evaluate Groundwater Quality in Varahi River Basin, Karnataka State, India. Applied Water Science, 1-11. 
https://doi.org/10.1007/s13201-015-0287-x

[37] Das, S. and Nag, S.K. (2015) Application of Multivariate Statistical Analysis Concepts for Assessment of Hydrogeochemistry of Groundwater-A Study in Suri I and II Blocks of Birbhum District, West Bengal, India. Applied Water Science, 1-16.

[38] Khan, T.A. (2015) Groundwater Quality Evaluation Using Multivariate Methods, in Parts of Ganga Sot Sub-Basin, Ganga Basin, India. Journal of Water Resource and Protection, 7, 769-780. https://doi.org/10.4236/jwarp.2015.79063

[39] Saleh, A., Al-Ruwaih, F. and Shehata, M. (1999) Hydrogeochemical Processes Operating within the Main Aquifers of Kuwait. Journal of Arid Environments, 42, 195-209. https://doi.org/10.1006/jare.1999.0511

[40] Ghabayen, M.S., Mckee, M. and Kemblowki, M. (2006) Ionic and Isotopic Ratios for Identification of Salinity Sources and Missing Data in Gaza Aquifer. Journal of Hydrology, 318, 360-373. https://doi.org/10.1016/j.jhydrol.2005.06.041

[41] Lee, J.Y. and Song, S.H. (2006) Evaluation of Ground Water Quality in Coastal Areas: Implications for Sustainable Agriculture. Environmental Geology, 50, 17-29.

[42] Pulido-Leboeuf, P. (2004) Seawater Intrusion and Associated Processes in a Small Complex Aquifer (Castell de Ferro, Spain). Applied Geochemistry, 19, 17-27. https://doi.org/10.1016/j.apgeochem.2004.02.004

[43] Milnes, E., Meilhac, C., Yeo, D., Renard, P., Hunkeler, D., Schnegg, P., et al. (2006) Hydrogeochemical and Hydrogeological Investigationin the Akrotiri Aquifer: Identification of Multiple Salnisation Processes and Implementation Criteria for Monitoring Networks. SWIM-SWICA.

[44] Cusimano, G., Hauser, S. and Vassallo, M. (2006) Hydrogeochemistry of a Wetland Area of South Western Sicily (Italy). E-Water. Official Publication of the European Water Association (EWA).

[45] Shangengana, E.S., Seely, M.K. and Sanderson, R.D. (2004) Major Ion Chemistry and Groundwater Salinization in Ephermeral Flood Plains in Some Arid Regions of Namibia. Journal of Arid Environments, 57, 71-83.

[46] Suthar, S., Bishnoi, P., Singh, S., Mutiyar, P.K., Nema, A.K. and Patil, N.S. (2009) Nitrate Contamination in Groundwater of Some Rural Areas of Rajasthan, India. Journal of Hazardous Materials, 171, 89-99. https://doi.org/10.1016/j.jhazmat.2009.05.111

[47] Zghibi, A., Zouhri, L., Tarhouni, J. and Kouzana, L. (2012) Groundwater Mineralisation Processes in Mediterranean Semiarid Systems (Cap-Bon, North East of Tunisia): Hydrogeological and Geochemical Approaches. Hydrological Processes, 27, 3227-3239.

[48] Slama, F., Bouhlila, R. and Renard, P. (2010) Identification of Groundwater Salinization Sources Using Experimental, Multivariate Statistical Analysis and Numerical Modelling Tools: Case of Korba Coastal Aquifer (Tunisia). 38 th International Association of Hydrogeologists Congress on Groundwater Quality Sustainability, Krakow, 12-17 September 2010.

[49] El Yaouti, F., El Mandour, A., Khattach, D., Benavente, J. and Kaufmann, O. (2009) Salinization Processes in the Unconfined Aquifer of Bou-Areg (NE Morocco). Applied Geochemistry, 24, 16-31. https://doi.org/10.1016/j.apgeochem.2008.10.005

[50] Kouzana, L., Ben Mammou, A. and Sfar Felfoul, M. (2009) Seawater Intrusion and Associated Processes: Case of the Korba Aquifer (Cap-Bon, Tunisia). Surface Geosciences (Hydrology-Hydrogeology). Comptes Rendus Geoscience, 341, 21-35. https://doi.org/10.1016/j.crte.2008.09.008

[51] Eneke, G.T., Ayonghe, S.N., Chandrasekharam, D., Ntchancho, R., Ako, A.A., 
Mouncherou, O.F., et al. (2011) Controls on Groundwater Chemistry in a Highly Urbanised Coastal Area. International Journal of Environmental Research, 5, 475-490.

[52] Batayneh, A.T. (2006) Use of Electrical Resistivity Methods for Detecting Subsurface Fresh and Saline Water and Delineating Their Interfacial Configuration: A Case Study of the Eastern Dead Sea Coastal Aquifers. Hydrogeology Journal, 14, 1277-1283. https://doi.org/10.1007/s10040-006-0034-3

[53] WHO (1989) Health Guidelines for the Use of Wastewater in Agriculture and Aquaculture. Report of WHO Scientific Group-Technical Report Series 778, WHO, Geneva, $74 \mathrm{p}$.

[54] WHO (2004) Guidelines for Drinking-Water Quality. 3rd Edition, Geneva, 514 p.

[55] Dinesh, K.T. and Singh Chandel, C.P. (2010) Analysis of the Major Ion Constituents in Groundwater of Jaipur City. Nature and Science, 8, 1-7.

[56] Deshpande, S.M. and Aher, K.R. (2012) Evaluation of Groundwater Quality and Its Suitability for Drinking and Agriculture Use in Parts of Vaijapur, District Aurangabad, MS. India Research Journal of Chemical Sciences, 2, 25-31.

[57] Wirmvem, M.J., Ohba, T., Fantong, W.Y., Ayonghe, S.N., Suila, J.Y., Asaah, A.N.E., et al. (2013) Hydrochemistry of Shallow Groundwater and Surface Water in the Ndop Plain, North West Cameroon. African Journal of Environmental Science and Technology, 7, 518-530. https://doi.org/10.5897/AJEST2013.1456

[58] Oyedele, K.F. and Momoh, E.I. (2009) Evaluation of Sea Water Intrusion in Freshwater Aquifers in a Lagoon Coast: A Case Study of the University of Lagos Lagoon, Akoka, Nigeria. New York Science Journal, 2, 32-42.

[59] Terzic, J., Markovic, T. and Pekas, Z. (2008) Influence of Sea-Water Intrusion and Agricultural Production on the Blato Aquifer, Island of Korcula, Croatia. Environmental Geology, 54, 719-729. https://doi.org/10.1007/s00254-007-0841-4

[60] Adebo, B.A. and Adetoyinbo, A.A. (2009) Assessment of Groundwater Quality in Unconsolidated Sedimentary Coastal Aquifer in Lagos State, Nigeria. Scientific Research and Essay, 4, 314-319. https://doi.org/10.1080/02626667609491674

[61] Adekunle, A.A. (2008) Delineation of Saltwater Intrusion into the Freshwater Aquifer of Lekki Peninsula, Lagos, Nigeria.

[62] Ginzburg, A. and Levanon, A. (1976) Determination of a Saltwater Interface by Electric Resistivity Depth Soundings. Hydrological Sciences-Bulletin, 21, 561-568.

[63] Tening, A.S., Chuyong, G.B., Asongwe, G.A., Fonge, B.A., Lifongo, L.L. and Tandia, B.K. (2013) Nitrate and Ammonium Levels of Some Water Bodies and Their Interaction with Some Selected Properties of Soils in Douala Metropolis, Cameroon. African Journal of Environmental Science and Technology, 7, 648-656.

[64] Fonteh, M.L., Fonkou, T. and Lambi, C.M. (2016) Stakeholder Perception of Global warming, Rainfall Variability and Sea Level Rise Hazard Perils in Three Coastal Districts of Douala-Cameroon. Journal of Environment and Earth Science, 6, 115-131.

[65] Fonteh, M.L., Fonkou, T.M., Lambi, C.M., Main, R., Ramoelo, A. and Cho, M.A. (2016) Assessing the Utility of Sentinel-1 C Band Synthetic Aperture Radar Imagery for Land Use Land Cover Classification in a Tropical Coastal Systems When Compared with Landsat 8. Journal of Geographic Information System, 8, 495-505. https://doi.org/10.4236/jgis.2016.84041 
Submit or recommend next manuscript to SCIRP and we will provide best service for you:

Accepting pre-submission inquiries through Email, Facebook, LinkedIn, Twitter, etc. A wide selection of journals (inclusive of 9 subjects, more than 200 journals)

Providing 24-hour high-quality service

User-friendly online submission system

Fair and swift peer-review system

Efficient typesetting and proofreading procedure

Display of the result of downloads and visits, as well as the number of cited articles Maximum dissemination of your research work

Submit your manuscript at: http://papersubmission.scirp.org/

Or contact jwarp@scirp.org 